\title{
Pengaruh Kompensasi, Komunikasi dan Disiplin Kerja Terhadap Kinerja Pegawai di Kecamatan Jambe Kabupaten Tangerang
}

\author{
Muhamad Husni Mubarok ${ }^{1}$ \\ Universitas Buddhi Dharma \\ mohammed.nie@gmail.com
}

\begin{abstract}
Abstrak
Penelitian ini dilakukan dengan menggunakan metode penelitian kuantitatif asosiatif. Jumlah sampel sebanyak 50 dari rumus sampel jenuh. Pengumpulan data diperoleh dari data primer dan data sekunder. Pengukuran instrument dilakukan menggunakan Skala Likert. Teknik analisa data yang digunakan adalah uji validitas, uji reabilitas, analisis berganda, analisis berganda, uji hipotesis dan koefisien determinasi (R2).

Hasil penelitian ini menunjukkan bahwa semua item pernyataan adalah valid dan reliable. Hal ini ditunjukkan dengan thitung yang diperoleh lebih besar daripada harga krisis (critical value/rtabel $=0,279$ ). Hipotesis penelitian diuji dengan thitung dan fhitung dari persamaan regresi $\alpha=5 \%$. Dari hasil perhitungan komputer program SPSS dihasilkan thitung dengan probabilitas sebagai berikut : Kompensasi (X1) sebesar 5,654 (signifikan 0,000); Komunikasi sebesar 6,555 (signifikan 0,000), Disiplin Kerja 6,173 (signifikan 0,000) dibandingkan dengan ttabel sebesar 2,010, ternyata thitung lebih besar sehingga hipotesis alternative (Ha) diterima.

Berdasarkan uji $\mathrm{f}$ diperoleh nilai fhitung $(20,044>2,81)$, hal ini berarti secara bersama-sama variabel independen (X) mempengaruhi atau dapat meningkatkan variabel dependen (Y), yaitu Kinerja Pegawai Koefisien Determinasi sebesar $\mathrm{R}=$ 0,753 maka R2 ( $\mathrm{R}$ square) sebesar 0,567. Hal ini menunjukkan bahwa pengaruh Kompensasi, Komunikasi dan Disiplin Kerja Terhadap Kinerja Pegawai sebesar 56,7\% sisanya 43,3\% disebabkan oleh faktor lain yang tidak diteliti tetapi turut menentukan.
\end{abstract}

\section{Kata Kunci : Kompensasi, Komunikasi, Disiplin Kerja dan Kinerja Pegawai}

\begin{abstract}
This research was conducted by using associative quantitative research method. The sample size is 50 from the saturated sample formula. Data collection is obtained from primary and secondary data. Measurement of the instrument is done using Likert Scale. Data analysis technique used is test of validity, reliability test, multiple regression analysis, multiple correlation analysis, hypothesis test and coefficient of determination (R2).

The results of this study indicate that all statement items are valid and reliable. This is indicated by thitung obtained greater than the crisis price (critical value / rtabel $=0.279$ ). The hypothesis of the study was tested by thitung and fcount from the regression equation $\alpha=5 \%$. From the computer calculation SPSS program generated thitung with probability as follows: Compensation (X1) of 5,654 (significant 0,000); Working Environment of 6,555 (significant 0,000), Work Discipline 6,173 (significant 0,000) compared with ttable of 2.010, greater than $t$ calculated so that alternative hypothesis $(\mathrm{Ha})$ is accepted.

Based on the test $f$ obtained value fhitung (20.044> 2.81), this means together independent variables $(X)$ affect or can increase the dependent variable $(Y)$, Employee Performance Coefficient Determination of $R=0.753$ then $R 2$ ( $R$ square) of 0.567. This indicates that the
\end{abstract}

${ }^{1}$ Korespondensi: Muhamad Husni Mubarok. Universitas Buddhi Dharma. Jl. Imam Bonjol No. 41 Karawaci Ilir-Tangerang. mohammed.nie@gmail.com 
influence of Compensation, Work Environment and Work Discipline on Employee Performance of $56.7 \% 43.3 \%$ is caused by other factors that are not examined but also determine.

\section{Keywords: Compensation, Communication, Work Discipline and Employee Performance}

\section{Pendahuluan}

Sistem organisasi pemerintahan suatu negara mempunyai andil besar dalam mencapai arah dan harapan pembangunan bagi masyarakatnya. Organisasi dalam pemerintahan dituntut untuk dapat memaksimalkan sumber daya manusia dan mengoptimalkan pengeloalaan sumber daya manusia itu. Karena keberhasilan suatu organisasi atau lembaga untuk mencapai tujuannya tidak terlepas kaitannya dari sumber daya yang dimiliki, sumber daya manusia yang akan mengatur dan mengelola sumber daya lain yang dimiliki organisasi atau lembaga untuk membantu mewujudkan tujuan organisasi dari suatu instansi itu sendiri.

Instansi kecamatan bukan saja membutuhkan pegawai yang kredibel, piawai, dan terampil, tetapi yang utama adalah mereka ulet dalam bekerja dan memiliki hasrat untuk mencapai hasil kerja yang terbaik. Kemampuan, kepiawaian, dan kesigapan pegawai tidak ada artinya bagi institusi, jika mereka tidak sungguh-sungguh mengembangkan dan mengelaborasikan keahlian mereka dalam bekerja, oleh karena itu, organisasi harus benar-benar memperhatikan faktor sumber daya manusianya. Salah satu hal yang terpenting dalam tata kelola sumber daya manusia adalah kinerja pegawai.

Instansi kecamatan sebagai sebuah institusi memerlukan pegawai yang memiliki kinerja yang gigih yang dapat mengejawantahkan maksud organisasi, oleh karena itu, camat beserta jajarannya sebagai pegawai kecamatan dituntut mampu memberikan kinerja yang optimal dalam melaksanakan pekerjaannya, sehingga secara bersama-sama dapat meraih hasil yang diharapkan. Seorang camat sebagai pimpinan memiliki tanggung jawab yang besar terhadap organisasi kecamatan, sehingga camat harus dapat mengarahkan, mengorganisasikan, dan mengendalikan secara tepat kepada pegawainya agar bersama-sama dapat meningkatkan kinerjanya sehingga arah dan maksud organisasi dapat tercapai. Di samping itu seorang camat harus bisa mengkoordinasi pada instansi-instansi vertikal lainnya.

Agar kinerja pegawai selalu konsisten maka setidaknya setiap organisasi perlu memperhatikan setidaknya seperti kompensasi, komunikasi dan disiplin kerja karena itu semua itu adalah faktor yang membentuk kinerja pegawai. Jika kompensasi, komunikasi dan disiplin kerja tidak diperhatikan dapat mempengaruhi kinerja pegawai tersebut. Karena kinerja yang diraih oleh pegawai sangat ditentukan oleh besarnya kompensasi yang didapat, Komunikasi yang nyaman bagi para pegawai, dan komunikasi yang dimiliki oleh pegawai menjadi salah satu pendukung peningkatan kinerja pegawai.

Kompensasi sangat signifikan terhadap kinerja pegawai. Salah satu alasan fundamental seseorang bekerja adalah untuk keberlangsungan hajat hidupnya. Seseorang akan bekerja keras agar mendapatkan kompensasi yang telah ditetapkan masalah penggajian berdasarkan posisi jabatan atau penempatan sedangkan kompensasi lain seperti pemberian bonus, tunjangan, honor atau insentif diatur oleh masing-masing lembaga. Menurut (Hasibuan, 2012) menyatakan bahwa kompensasi adalah seluruh imbalan dengan bentuk apapun baik langsung maupun tidak langsung, baik berupa uang maupun barang yang diperoleh pegawai. Oleh karena itu, Kompensasi yang diterima yaitu bisa berupa finansial maupun non finansial. Kegiatan ini meliputi penetapan sistem kompensasi yang mampu memotivasi kinerja pegawai dan juga memperhatikan besar kecilnya kompensasi yang akan diterima oleh setiap pegawai. Penawaran kompensasi yang sesuai akan menentukan komitmen pada setiap pegawai untuk tetap meningkatkan kinerjanya. Kompensasi diberikan agar para pegawai dapat bekerja secara maksimal sehingga dapat menghasilkan kinerja yang optimal. Kompensasi adalah sejumlah paket yang diberikan setiap organisasi kepada 
pekerjanya sebagai honorarium atas jasa dan tenaga kerjanya. Maka dari itu kebijakan kompensasi bagi pegawai berazaskan pada penilaian kinerja, kondisi pegawai, jabatan, tingkat pendidikan dan masa kerja pegawai tersebut.

Setelah kompensasi, salah satu faktor yang harus diperhatikan lagi yaitu komunikasi antar pegawai maupun antara atasan dan bawahan. Komunikasi juga menjadi kunci sukses bagi keberhasilan suatu organisasi. Komunikasi yang baik dapat menentukan dalam mengarahkan sikap dan kepribadian seseorang untuk bersikap dan berperilaku sesuai dengan aturan yang telah ditentukan supaya dapat tercapainya tujuan organisasi. Semakin mampu seseorang mengendalikan komunikasi berarti seseorang tersebut mampu mengendalikan lingkungannya. (Mulyana, 2011), Seseorang akan memiliki pengetahuan baru serta mengubah pandangan dan perilakunya setelah mendapatkan komunikasi.

Selanjutnya adalah disiplin kerja. (Veithzal \& Sagala, 2009) disiplin kerja menjadi ukuran atasan agar pegawai dapat merubah cara kerja, memperbaiki sikap dan meningkatkan kesadaran dan untuk menaati peraturan dan norma yang telah dibangun perusahaan.

Seorang pimpinan dikatakan baik dalam memimpin bila para pegawainya mempunyai tingkat disiplin kerja yang tinggi. Dalam kedudukannya sebagai pimpinan organisasi pemerintahan tingkat kecamatan, Camat dituntut untuk lebih aktif dan secara terus-menerus mengupayakan langkah-langkah dalam rangka peningkatan kinerja pegawai agar dapat meningkatkan pelayanan umum pada masyarakat khususnya masyarakat yang ada di lingkungan kecamatan serta menentukan pola pembinaan yang tepat untuk mennjalankan institusi yang dipimpinnya.

\section{Metode Penelitian/Method}

Metode yang digunakan dalam penelitian ini adalah metode penelitian kuantitatif asosiatif yang dimaksudkan untuk memberikan gambaran secara jelas mengenai masalah-masalah yang diteliti dalam bentuk hubungan sebab-akibat (causal effect) menginterprestasikan serta menjelaskan data secara sistematis.

Populasi dalam penelitian ini adalah pegawai Kecamatan Jambe Kabupaten Tangerang dengan pegawai yang berjumlah 50 orang. Karena terbatasnya jumlah populasi, maka keseluruhan anggota populasi dijadikan sampel penelitian yaitu 50 orang sebagai sampel, sehingga metode pengambilan sampel yang digunakan adalah teknik sensus atau sampel jenuh.

Dalam penelitian ini penulis mencari data-data yang dibutuhkan yaitu berupa data primer berupa melalui kuesioner dan wawancara mengenai variabel yang diteliti dan data sekunder berupa sumber dari buku-buku, internet, dan jurnal yang sifatnya membantu dan memberikan informasi untuk bahan penelitian. Metode pengumpulan data dalam penelitian ini dilakukan dengan cara :

1. Studi Kepustakaan (Library Research) yaitu pengumpulan data yang dilakukan dengan mempelajari dan menganalisis buku atau bahan-bahan tertulis lainnya yang ada hubungan dengan penelitian yang dilakukan.

2. Studi Lapangan (Fied Research) yaitu kegiatan pengumpulan data dengan cara melakukan penelitian langsung ke lokasi penelitian dengan cara :

a. Observasi yaitu pengumpulan data dan informasi dengan cara langsung diinstansi.

b. Wawancara yaitu pengumpulan data dengan melakukan wawancara dan langsung beratatap muka dengan narasumber.

c. Angket (kuesioner) yaitu pengumpulan data dengan mengajukan daftar pertanyaan tertulis kepada responden.

Dalam penelitian ini metode pengumpulan data menggunakan kuesioner. Instrumen pertanyaan dalam lembar kuesioner dibuat dalam skala likert. Skala likert digunakan untuk mengukur sikap, pendapat dan persepsi seseorang atau sekelompok orang tentang fenomena sosial. Jawaban setiap 
item intrumen mempunyai tingkat dari sangat positif sampai negatif yang berupa kata-kata dengan skor :

Tabel 1. Skala Penilaian Kuesioner

\begin{tabular}{lc}
\hline \multicolumn{1}{c}{ Kategori } & Nilai \\
\hline Sangat Setuju & 5 \\
Setuju & 4 \\
Ragu Ragu & 3 \\
Tidak Setuju & 2 \\
Sangat Tidak Setuju & 1 \\
\hline
\end{tabular}

Sumber : Sugiyono (2011:94)

Menurut (Sugiyono, 2012) mengemukakan bahwa operasional variabel adalah menempatkan arti pada suatu konstruk atau variabel dengan cara menetapkan kegiatan-kegiatan atau tindakantindakan yang perlu untuk mengukur suatu variabel penelitian. Dalam melakukan penelitian ini, penulis menggunakan variabel yang terdiri dari dua variabel bebas dan satu variabel terikat.

1. Variabel Independen dalam penelitian ini yang merupakan variabel bebasnya adalah:

a. Pengaruh Kompensasi (X1)

b. Pengaruh Komunikasi (X2)

c. Pengaruh Disiplin Kerja (X3)

2. Variabel Dependen dalam penelitian ini adalah Kinerja Pegawai (Y).

Instrumen penelitian sebelum digunakan untuk memperoleh data-data penelitian, terlebih dahulu dilakukan uji coba agar diperoleh instrumen yang valid dan realibilitas. Uji validitas dilakukan untuk melihat sejauh mana ketepatan dan kecermatan alat ukur dalam melakukan fungsi ukurannya.

Tabel 2. Instrumen Penelitian

\begin{tabular}{|c|c|c|}
\hline Variabel Penelitian & Instrumen Penelitian & Item \\
\hline \multirow[t]{4}{*}{ Kompensasi $\left(\mathrm{X}_{1}\right)$} & 1. Upah dan Gaji & $1 \mathrm{~s} / \mathrm{d} 10$ \\
\hline & 2. Insentif & \\
\hline & 3. Tunjangan & \\
\hline & 4. Bonus & \\
\hline \multirow{5}{*}{ Komunikasi $\left(\mathrm{X}_{2}\right)$} & 1. Saluran komunikasi & $1 \mathrm{~s} / \mathrm{d} 10$ \\
\hline & 2. Jaringan komunikasi & \\
\hline & 3. Jenis komunikasi & \\
\hline & 4. Hambatan komunikasi & \\
\hline & 1. Ketaatan pada Peraturan & $1 \mathrm{~s} / \mathrm{d} 10$ \\
\hline \multirow[t]{5}{*}{ Disiplin Kerja $\left(\mathrm{X}_{3}\right)$} & 2. Kepatuhan terhadap Perintah & \\
\hline & 3. Ketaatan terhadap Jam Kerja & \\
\hline & 4. Kepatuhan Berpakaian Seragam & \\
\hline & $\begin{array}{l}\text { 5. Kepatuhan dalam penggunaan } \\
\text { dan pemeliharaan sarana kantor }\end{array}$ & \\
\hline & 6. Selalu bekerja sesuai prosedur & \\
\hline \multirow[t]{4}{*}{ Kinerja Pegawai (Y) } & 1. Kualitas Kerja & $1 \mathrm{~s} / \mathrm{d} 10$ \\
\hline & 2. Kuantitas Kerja & \\
\hline & 3. Pengetahuan & \\
\hline & 4. Kerjasama & \\
\hline
\end{tabular}

Teknik analisis data merupakan cara peneliti gunakan untuk menganalisis data yang diperoleh dan memperoleh jawaban serta kesimpulan dari permasalahan penelitian diantaranya adalah:

1. Uji Validitas dan Realibilitas

2. Analisis Regresi Linear Berganda

3. Analisis Korelasi Berganda 
4. Uji Hipotesis
a. Uji T
b. Uji F
c. Analisis Koefisien Determinasi

\section{Hasil/Result}

Tabel 3. Deskripsi Statistik

\begin{tabular}{|c|c|c|c|c|c|c|c|c|c|}
\hline & \multirow{2}{*}{$\begin{array}{r}\mathrm{N} \\
\text { Stat } \\
\end{array}$} & \multirow{2}{*}{$\begin{array}{r}\text { Range } \\
\text { Stat }\end{array}$} & \multirow{2}{*}{$\begin{array}{c}\text { Minimum } \\
\text { Stat }\end{array}$} & \multirow{2}{*}{$\begin{array}{c}\text { Maximum } \\
\text { Stat } \\
\end{array}$} & \multirow{2}{*}{$\begin{array}{l}\text { Sum } \\
\text { Stat }\end{array}$} & & Variance \\
\hline & & & & & & Stat & $\begin{array}{l}\text { Std. } \\
\text { Error }\end{array}$ & Stat & Stat \\
\hline Kompensasi & 50 & 23 & 24 & 47 & 1966 & 39,32 & ,694 & 4,909 & 24,100 \\
\hline Komunikasi & 50 & 20 & 29 & 49 & 2064 & 41,28 &, 717 & 5,067 & 25,675 \\
\hline Disiplin Kerja & 50 & 19 & 30 & 49 & 2078 & 41,56 &, 713 & 5,039 & 25,394 \\
\hline Kinerja Pegawai & 50 & 13 & 37 & 50 & 2199 & 43,98 & ,526 & 3,717 & 13,816 \\
\hline Valid N (listwise) & 50 & & & & & & & & \\
\hline
\end{tabular}

Sumber: data diolah menggunakan spss 25, tahun 2018

Berdasarkan tabel diatas diketahui deskripsi dari variabel Kompensasi, Komunikasi, Disiplin Kerja dan Kinerja Pegawai. Hasil dari perhitungan SPSS 25 pada variabel Kompensasi menunjukan jumlah responden $(\mathrm{N})$ ada 50, dari 50 responden ini nilai terkecil (Minimum) adalah 24 dan nilai terbesar (Maksimum) adalah 47, rata-rata nilai dari 50 responden adalah 39,32 dengan standar deviasi 4,909. Variabel Komunikasi menunjukan jumlah responden (N) ada 50, dari 50 responden ini nilai terkecil (Minimum) adalah 29 dan nilai terbesar (Maksimum) adalah 49, rata-rata nilai dari 50 responden adalah 41,28 dengan standar deviasi 5,067. Variabel Disiplin Kerja menunjukan jumlah responden $(\mathrm{N})$ ada 50, dari 50 responden ini nilai terkecil (Minimum) adalah 30 dan nilai terbesar (Maksimum) adalah 49, rata-rata nilai dari 50 responden adalah 41,56 dengan standar deviasi 5,039. Variabel Kinerja Pegawai menunjukan jumlah responden (N) ada 50, dari 50 responden ini nilai terkecil (Minimum) adalah 37 dan nilai terbesar (Maksimum) adalah 50, rata-rata nilai dari 50 responden adalah 43,96 dengan standar deviasi 3,717.

\section{Deskripsi Responden}

Responden dalam penelitian ini adalah pegawai Kecamatan Jambe Kabupaten Tangerang, yang keseluruhan populasinya adalah berjumlah 50 orang pegawai. Dari jumlah populasi tersebut maka diambil keseluruhan jumlah pegawai sebagai sampel dalam penelitiannya, dari 50 kuesioner yang disebar maka semua kuesioner yang kembali sebanyak 50 dan dapat diolah lebih lanjut. Deskripsi responden dalam penelitian ini untuk menguraikan identitas responden, berdasarkan jenis kelamin, jenis usia dan jenis pendidikan dapat dilihat melalui tabel berikut ini:

\section{Karakteristik Responden Berdasarkan Jenis Kelamin}

Menurut jenis kelamin responden maka terbagi atas dua yakni pria dan wanita, dimana pengelompokan responden berdasarkan jenis kelamin dapat dilihat sebagai berikut: 
Tabel 4. Karakteristik Responden Berdasarkan Jenis Kelamin

\begin{tabular}{cccccc}
\hline & & Frequency & Percent & Valid Percent & Cumulative Percent \\
\hline Valid & Pria & 41 & 82,0 & 82,0 & 82,0 \\
& Wanita & 9 & 18,0 & 18,0 & 100,0 \\
& Total & 50 & 100,0 & 100,0 & \\
\hline
\end{tabular}

Sumber: data diolah menggunakan spss 25 , tahun 2018

Berdasarkan tabel diatas diperoleh data bahwa jumlah responden terbanyak berdasarkan jenis kelamin adalah didominasi oleh responden pria dengan jumlah responden sebanyak 41 orang atau $82,0 \%$, diikuti oleh responden wanita yakni sebanyak 9 orang atau 18,0\%, hal ini menunjukan bahwa sebagian besar pegawai yang bekerja di Kecamatan Jambe Kabupaten Tangerang adalah pegawai pria.

Tabel 5. Karakteristik Responden Berdasarkan Usia

\begin{tabular}{cccccc}
\hline & & Frequency & Percent & Valid Percent & Cumulative Percent \\
\hline Valid & $>20$ & 10 & 20,0 & 20,0 & 20,0 \\
& $>30$ & 10 & 20,0 & 20,0 & 40,0 \\
& $>40$ & 30 & 60,0 & 60,0 & 100,0 \\
& Total & 50 & 100,0 & 100,0 & \\
\hline
\end{tabular}

Sumber: data dioleh menggunakan spss 25, tahun 2018

Berdasarkan tabel diatas dapat dilihat berdasarkan usia responden. Diketahui bahwa jumlah responden yang telah mengisi kuesioner berjumlah 50 responden, dimana jumlah usia responden yang telah berusia >20 tahun adalah 10 responden dengan presentase $20,0 \%$ dan jumlah responden yang usianya $>30$ tahun adalah 10 responden dengan presentase $20,0 \%$ dan jumlah responden yang telah berusia $>40$ tahun adalah 30 responden dengan presentase $60,0 \%$.

\section{Pendidikan Responden}

Dari hasil penelitian yang dilakukan, diperoleh presentase tingkat pendidikan responden SMA, Diploma dan Sarjana.

Tabel 6. Pendidikan Responden

\begin{tabular}{cccccc}
\hline & & & & & Cumulative \\
Valid & SMA & 28 & 56,0 & 56,0 & 56,0 \\
& D3 & 6 & 12,0 & 12,0 & 68,0 \\
S1 & 13 & 26,0 & 26,0 & 94,0 \\
& S2 & 3 & 6,0 & 6,0 & 100,0 \\
& Total & 50 & 100,0 & 100,0 & \\
\hline \multicolumn{7}{c}{ Sumber: }
\end{tabular}

Sumber: Data diolah menggunakan spss 25, tahun 2018

Berdasarkan tabel diatas maka diperoleh data bahwa jumlah responden terbanyak menurut jenis pendidikan adalah didominasi jenis pendidikan S2 dengan jumlah responden sebanyak 3 orang atau 6,0\%, kemudian diikuti oleh responden yang lulusan Diploma sebanyak 6 orang atau 12,0\%, lalu responden yang lulusan S1 yakni sebanyak 13 orang atau 26,0\% dan responden yang lulusan SMA yakni sebanyak 28 orang atau 56,0\%. Hal ini menunjukan bahwa rata-rata pegawai yang bekerja di Kecamatan Jambe Kabupaten Tangerang adalah lulusan SMA. 


\section{Analisis Data}

\section{Uji Validitas}

Setelah data dikumpulkan melalui penyebaran kuesioner/angket, maka selanjutnya adalah melakukan pengolahan data agar data bisa disajikan sebagai informasi dalam bentuk tabel dan angka. Sebelum data diolah lebih lanjut maka sangat perlu dipastikan data yang diperoleh dari beberapa pertanyaan yang diajukan kepada responden adalah Valid atau Reliabel. Untuk menguji validitas data, maka penulis menggunakan bantuan software SPSS 25 IBM, yang hasilnya dapat dilihat pada tabel berikut ini:

Tabel 7. Hasil Rangkuman Uji Validitas Kompensasi $\left(\mathrm{X}_{1}\right)$

\begin{tabular}{|c|c|c|c|}
\hline Pernyataan & rhitung & $r_{\text {tabel }}$ & Keterangan \\
\hline $\begin{array}{l}\text { 1. Gaji sesuai UMR (upah minimum } \\
\text { regional) }\end{array}$ &, $629^{* * *}$ & 0,279 & Valid \\
\hline $\begin{array}{l}\text { 2. Gaji sesuai dengan tingkat } \\
\text { pendidikan dan jabatan }\end{array}$ &, $535^{* *}$ & 0,279 & Valid \\
\hline $\begin{array}{l}\text { 3. Perbedaan gaji antar jabatan dalam } \\
\text { kantor sesuai dengan harapan }\end{array}$ &, $364^{* *}$ & 0,279 & Valid \\
\hline $\begin{array}{l}\text { 4. Pemberian bonus atau insentif pasca } \\
\text { penyelenggaraan kegiatan sesuai } \\
\text { harapan }\end{array}$ & $671^{* *}$ & 0,279 & Valid \\
\hline $\begin{array}{l}\text { 5. Penghargaan atau reward pegawai } \\
\text { sesuai dengan pendidikan dan } \\
\text { jabatan }\end{array}$ &, $650^{* *}$ & 0,279 & Valid \\
\hline $\begin{array}{l}\text { 6. Fasilitas yang diberikan sesuai } \\
\text { dengan jabatan dan penempatan }\end{array}$ & ,297* & 0,279 & Valid \\
\hline $\begin{array}{l}\text { 7. Pemberian tunjangan untuk anak dan } \\
\text { istri sesuai dengan harapan }\end{array}$ &, $729^{* *}$ & 0,279 & Valid \\
\hline $\begin{array}{l}\text { 8. Pemberian dana pensiunan pegawai } \\
\text { sesuai harapan }\end{array}$ &, $744^{* *}$ & 0,279 & Valid \\
\hline $\begin{array}{l}\text { 9. Kepuasan dengan jaminan sosial } \\
\text { tenaga kerja yang diberikan instansi }\end{array}$ &, $639^{* *}$ & 0,279 & Valid \\
\hline $\begin{array}{l}\text { 10. Bonus yang diberikan sudah sesuai } \\
\text { dengan waktu kerja yang ditentukan }\end{array}$ &, $832^{* *}$ & 0,279 & Valid \\
\hline
\end{tabular}

Sumber: data diolah menggunakan spss 25, tahun 2018

Berdasarkan tabel diatas menunjukkan semua item pernyataan X1 memiliki nilai lebih besar dari 0,279, maka dapat disimpulkan bahwa item pernyataan variabel X1 (Kompensasi) dinyatakan valid.

Tabel 8. Hasil Rangkuman Uji Validitas Komunikasi $\left(\mathrm{X}_{2}\right)$

\begin{tabular}{llrrr}
\hline \multicolumn{1}{c}{ Pernyataan } & rhitung & r tabel & Keterangan \\
\hline 1. Mengatasi Masalah dengan dialog &, $877^{* *}$ & 0,279 & Valid \\
2. Melakukan instruksi langsung dan tidak langsung &, $727^{* *}$ & 0,279 & Valid \\
3. Memperingatkan bawahan dengan kata-kata yang &, $615^{* *}$ & 0,279 & Valid \\
sopan & & & \\
4. Smengutamakan diskusi bersama sebelum &, $812^{* *}$ & 0,279 & Valid \\
melakukan proyek & & & \\
5. Memberikan kesempatan bawahan untuk berbicara &, $877^{* *}$ & 0,279 & Valid \\
6. Memfasilitasi sarana komunikasi dan informasi &, $346^{*}$ & 0,279 & Valid \\
bagi pegawai & & & \\
7. Mengedepankan keterbukaan informasi untuk &, $469^{* *}$ & 0,279 & Valid \\
\hline
\end{tabular}


masyarakat

8. Pimpinan selalu memberikan perhatian pada pegawainya (perhatian ini berupa sapaan kepada para pegawai)

9. Membangun hubungan kerja baik dengan pimpinan maupun dengan sesama rekan kerja

10. Komunikasi yang baik antara rekan kerja, atasan dengan bawahan dapat membantu kelancaran pelaksanaan pekerjaan

Sumber: data diolah menggunakan spss 25, tahun 2018

Berdasarkan tabel diatas menunjukkan semua item pernyataan X2 memiliki nilai lebih besar dari 0,279, maka dapat disimpulkan bahwa item pernyataan variabel X2 (Komunikasi) dinyatakan valid.

Tabel 9. Hasil Rangkuman Uji Validitas Disiplin Kerja $\left(\mathrm{X}_{3}\right)$

\begin{tabular}{llccr}
\hline Pernyataan & rhitung & r tabel & Keterangan \\
\hline 1. Selalu taat menjalankan tugas pokok &, $796^{* *}$ & 0,279 & Valid \\
2. Selalu taat menjalankan wewenang &, $713^{* *}$ & 0,279 & Valid \\
3. Selalu patuh melaksanakan tugas &, $557^{* *}$ & 0,279 & Valid \\
kedinasan & & & \\
4. Selalu datang tepat waktu &, $811^{* *}$ & 0,279 & Valid \\
5. Selama jam kerja selalu berada di &, $883^{* *}$ & 0,279 & Valid \\
dalam kantor & & & \\
6. Selalu taat memakai pakaian &, $407^{* *}$ & 0,279 & Valid \\
seragam dinas pada setiap hari kerja & & & \\
7. Selalu menjaga kebersihan &, $483^{* *}$ & 0,279 & Valid \\
bangunan kantor &, $449^{* *}$ & 0,279 & Valid \\
8. Selalu taat menjaga peralatan kantor &, $583^{* *}$ & 0,279 & Valid \\
9. Selalu taat menjalankan prosedur & & & \\
kerja &, $883^{* *}$ & 0,279 & Valid \\
10. Selalu menjaga kualitas hasil kerja
\end{tabular}

Sumber: data diolah menggunakan spss 25, tahun 2018

Berdasarkan tabel diatas menunjukkan semua item pernyataan $\mathrm{X}_{3}$ memiliki nilai lebih besar dari 0,279 , maka dapat disimpulkan bahwa item pernyataan variabel $\mathrm{X}_{3}$ (Disiplin Kerja) dinyatakan valid.

Tabel 10. Hasil Rangkuman Uji Validitas Kinerja Pegawai (Y)

\begin{tabular}{llcc}
\hline \multicolumn{1}{c}{ Pernyataan } & ${ }^{\text {rhitung }}$ & ${ }^{\text {rtabel }}$ & Keterangan \\
\hline 1. Pekerjaan yang dilakukan sudah &, $719^{* *}$ & 0,279 & Valid \\
$\begin{array}{l}\text { Sesuai dengan Standar Kerja } \\
\text { Pekerjaan yang dilakukan sudah } \\
\text { tepat waktu }\end{array}$ &, $722^{* *}$ & 0,279 & Valid \\
$\begin{array}{l}\text { 3. Pekerjaan yang dilakukan sudah } \\
\text { akurat }\end{array}$ &, $538^{* *}$ & 0,279 & Valid \\
$\begin{array}{l}\text { 4arget kerja yang telah ditetapkan } \\
\text { sudah berhasil dicapai }\end{array}$ &, $820^{* *}$ & 0,279 & Valid \\
5. Volume pekerjaan yang &, $842^{* *}$ & 0,279 & Valid \\
\hline
\end{tabular}




\begin{tabular}{|c|c|c|c|}
\hline $\begin{array}{l}\text { dilakukan telah sesuai dengan } \\
\text { harapan atasan }\end{array}$ & & & \\
\hline $\begin{array}{l}\text { 6. Mampu memenuhi tugas-tugas } \\
\text { yang berkaitan dengan pekerjaan }\end{array}$ &, $841^{* *}$ & 0,279 & Valid \\
\hline $\begin{array}{l}\text { 7. Mampu menyelesaikan pekerjaan } \\
\text { insidentil yang ditugaskan atasan }\end{array}$ &, $774^{* *}$ & 0,279 & Valid \\
\hline $\begin{array}{l}\text { 8. Mampu bekerja sama dengan } \\
\text { rekan kerja }\end{array}$ &, $561^{* *}$ & 0,279 & Valid \\
\hline $\begin{array}{l}\text { 9. Bersikap positif terhadap setiap } \\
\text { pekerjaan tim }\end{array}$ &, $594^{* *}$ & 0,279 & Valid \\
\hline $\begin{array}{l}\text { 10. Bersedia membantu anggota tim } \\
\text { kerja dalam menyelesaikan } \\
\text { pekerjaan }\end{array}$ &, $788^{* *}$ & 0,279 & Valid \\
\hline
\end{tabular}

Sumber: data diolah menggunakan spss 25, tahun 2018

Berdasarkan tabel diatas menunjukkan semua item pernyataan Y memiliki nilai lebih besar dari 0,279, maka dapat disimpulkan bahwa item pernyataan variabel Y (Kinerja Pegawai) dinyatakan valid.

\section{Hasil Uji Reabilitas}

Pengujian reliabilitas instrumen dalam suatu penelitian dilakukan karena keterandalan instrumen berkaitan dengan keajekan dan taraf kepercayaan terhadap instrumen penelitian tersebut, dalam penentuan tingkat reabilitas suatu instrumen penelitian dapat diterima apabila memiliki koefisien alpha lebih besar dari 0,60. Berikut ini hasil dari uji reabilitas untuk variabel Kompensasi, Komunikasi, Disiplin Kerja dan Kinerja Pegawai.

\section{Kompensasi}

Tabel 11. Reliability Statistics Kompensasi

\begin{tabular}{cc}
\hline Cronbach's Alpha & N of Items \\
\hline, 818 & 10
\end{tabular}

Sumber: data diolah menggunakan spss 25, tahun 2018

Berdasarkan tabel diatas dalam uji reabilitas diketahui bahwa nilai Alpha Cronbach $>0,60$ yakni $(0,818>0,60)$ maka, kuesioner tersebut dinamakan reliabel.

\section{Komunikasi}

Tabel 12. Reliability Statistics Komunikasi

\begin{tabular}{c|c}
\hline Cronbach's Alpha & N of Items \\
\hline, 865 & 10 \\
\hline
\end{tabular}

Sumber: data diolah menggunakan spss 25, tahun 2018

Berdasarkan tabel diatas. dalam uji reabilitas diketahui bahwa nilai Alpha Cronbach $>0,60$ yakni $(0,865>0,60)$ maka, kuesioner tersebut dinamakan reliabel.

\section{Disiplin Kerja}

Tabel 13. Reliability Statistics Displin Kerja

\begin{tabular}{cc}
\hline Cronbach's Alpha & N of Items \\
\hline, 863 & 10 \\
\hline
\end{tabular}

Sumber: data diolah menggunakan spss 25, tahun 2018 
Berdasarkan tabel diatas. dalam uji reabilitas diketahui bahwa nilai Alpha Cronbach $>0,60$ yakni $(0,863>0,60)$ maka, kuesioner tersebut dinamakan reliabel.

\section{Kinerja Pegawai}

\begin{tabular}{cc} 
Tabel 14. Reliability Statistics Kinerja Pegawai \\
\hline Cronbach's Alpha & N of Items \\
\hline, 897 & 10 \\
\hline
\end{tabular}

Sumber: data diolah menggunakan spss 25, tahun 2018

Berdasarkan tabel diatas. dalam uji reabilitas diketahui bahwa nilai Alpha Cronbach>0,60 yakni $(0,897>0,60)$ maka, kuesioner tersebut dinamakan reliabel.

Coefficients $^{\mathrm{a}}$

Tabel 15. Regresi Linear Berganda

\begin{tabular}{llccccc}
\hline & & \multicolumn{2}{c}{ Unstandardized } & \multicolumn{2}{c}{$\begin{array}{c}\text { Standardized } \\
\text { Coefficients }\end{array}$} & \multicolumn{2}{c}{ Coefficients } & & \\
\cline { 3 - 5 } & \multicolumn{1}{c}{ Model } & B & Std. Error & Beta & t & Sig. \\
\hline \multirow{2}{*}{ (Constant) } & 18,236 & 3,430 & & 5,316 &, 000 \\
& Kompensasi &, 279 &, 090 &, 369 & 3,114 &, 003 \\
& Komunikasi &, 316 &, 402 &, 431 &, 787 &, 436 \\
& Disiplin Kerja &, 041 &, 392 &, 056 &, 106 &, 916
\end{tabular}

a. Dependent Variable: Kinerja Pegawai

Sumber: data diolah menggunakan spss 25, tahun 2018

Berdasarkan tabel diatas nilai a (constan) $=18,236$ dan nilai $b_{1}=0,279 b_{2}=0,316$ dan $b_{3}=0,041$ maka persamaan regresinya adalah:

1. Nilai konstanta $(\alpha)$

$$
Y=18,236+0,279 X_{1}+0,316 X_{2}+0,041 X_{3}
$$

Ini berarti jika semua variabel bebas memliki nilai nol (0) maka nilai variabel terikat (Beta) sebesar 18,236.

2. Kompensasi $\left(\mathrm{X}_{1}\right)$ terhadap Kinerja Pegawai (Y)

Nilai $b_{1}=0,279$ artinya jika penambahan sebesar satuan Kompensasi, maka penilaian Kompensasi terhadap Kinerja Pegawai bertambah sebesar 0,279.

3. Komunikasi $\left(\mathrm{X}_{2}\right)$ terhadap Kinerja Pegawai (Y)

Nilai $b_{2}=0,316$ artinya jika penambahan sebesar satuan Kompensasi, maka penilaian Kompensasi terhadap Kinerja Pegawai bertambah sebesar 0,316.

4. Disiplin Kerja $\left(\mathrm{X}_{3}\right)$ terhadap Kinerja Pegawai (Y)

Nilai $b_{3}=0,041$ artinya jika penambahan sebesar satuan Kompensasi, makan penilaian Kompensasi terhadap Kinerja Pegawai bertambah sebesar 0,041.

\section{Analisa Hasil Pengujian Korelasi Berganda}

Korelasi berganda ini untuk mengetahui hubungan antara variabel independen, Kompensasi, Komunikasi dan Disiplin Kerja terhadap variabel dependen yaitu Kinerja Pegawai.

Korelasi Berganda $\left(X_{1}, X_{2}, X_{3}\right.$ Terhadap $\left.Y\right)$ 
Tabel 16. Korelasi Berganda

Model Summary

\begin{tabular}{ccccc}
\hline Model & $\mathrm{R}$ & $\mathrm{R}$ Square & Adjusted R Square & Std. Error of the Estimate \\
\hline 1 &, $753^{\mathrm{a}}$ &, 567 &, 538
\end{tabular}

a. Predictors: (Constant), Disiplin Kerja, Kompensasi, Komunikasi

b. Dependen Variable : Kinerja Pegawai

Sumber: data diolah menggunakan spss 25, tahun 2018

Berdasarkan variabel 4.50. maka diketahui bahwa nilai korelasi berganda antara $\mathrm{X}_{1}, \mathrm{X}_{2}, \mathrm{X}_{3}$ Terhadap Y sebesar 0,753 atau (75,3\%) artinya Kompensasi, Komunikasi dan Disiplin Kerja Terhadap Kinerja Pegawai adalah kuat.

\section{Penguji Hipotesis}

\section{Uji t (Parsial)}

Untuk membuktikan hipotesis dalam penelitian ini apakah variabel bebas berpengaruh terhadap variabel terikat, maka digunakan Uji t untuk menguji apakah masing-masing variabel bebas berpengaruh secara signifikan terhadap variabel terikat (Yanti \& Oktari, 2018).

Tabel 17. Uji t Kompensasi Terhadap Kinerja Pegawai (Parsial)

\section{Coefficients $^{\mathrm{a}}$}

\begin{tabular}{llccccc}
\hline & \multicolumn{5}{c}{$\begin{array}{c}\text { Unstandardized } \\
\text { Coefficients }\end{array}$} & \multicolumn{2}{c}{$\begin{array}{c}\text { Standardized } \\
\text { Coefficients }\end{array}$} & & \\
\cline { 3 - 5 } & Model & B & Std. Error & Beta & T & Sig. \\
\hline 1 & (Constant) & 25,156 & 3,355 & & 7,499 &, 000 \\
& Kompensasi &, 479 &, 085 &, 632 & 5,654 &, 000 \\
\hline
\end{tabular}

a. Dependent Variable: Kinerja Pegawai

Sumber: data diolah menggunakan spss 25, tahun 2018

Untuk menguji hipotesis yang bersifat parsial antara Kompensasi $\left(\mathrm{X}_{1}\right)$ terhadap Kinerja Pegawai (Y) digunakan uji t. Berdasarkan tabel 4.52. diatas menunjukkan hasil uji t hitung sebesar 5,654 dan angka signifikasi sebesar 0,000. Besar nilai t tabel dengan tingkat $\alpha=5 \%(0,05)$, derajat kebebasan n-2 $(50-2=48)$. Maka diperoleh nilai $\mathrm{t}$ tabel $=2,010$ dikarenakan $\mathrm{t}$ hitung $>\mathrm{t}$ tabel yaitu 5,654 > 2,010 maka $\mathrm{H}_{\mathrm{o}}$ ditolak dan $\mathrm{H}_{\mathrm{a}}$ diterima, yang artinya Kompensasi $\left(\mathrm{X}_{1}\right)$ berpengaruh secara positif dan signifikan terhadap Kinerja Pegawai (Y).

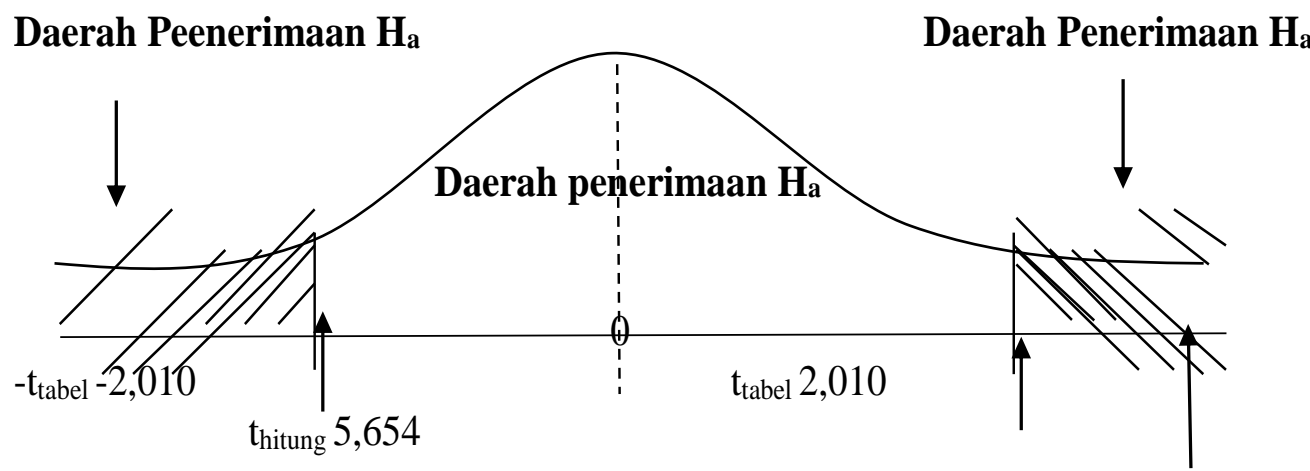

Gambar 1. Kurva Uji t Kompensasi ( $\left.\mathrm{X}_{1}\right)$ Terhadap Kinerja Pegawai (Y) 
Tabel 18. Uji t Komunikasi Terhadap Kinerja Pegawai

\section{Coefficients $^{\mathbf{a}}$}

\begin{tabular}{|c|c|c|c|c|c|c|}
\hline & \multirow[b]{2}{*}{ Model } & \multicolumn{2}{|c|}{$\begin{array}{c}\text { Unstandardized } \\
\text { Coefficients }\end{array}$} & \multirow{2}{*}{ 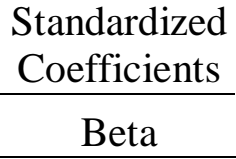 } & \multirow[b]{2}{*}{$\mathrm{t}$} & \multirow[b]{2}{*}{ Sig. } \\
\hline & & B & Std. Error & & & \\
\hline \multirow[t]{2}{*}{1} & (Constant) & 23,168 & 3,198 & & 7,244 & ,000 \\
\hline & Komunikasi & ,504 & ,077 & 687 & 6,555 & ,000 \\
\hline
\end{tabular}

a. Dependent Variable: Kinerja Pegawai

Sumber: data diolah menggunakan spss 25, tahun 2018

Untuk menguji hipotesis yang bersifat parsial antara Komunikasi $\left(\mathrm{X}_{2}\right)$ terhadap Kinerja Pegawai (Y) digunakan uji t. Berdasarkan tabel 4.53. diatas menunjukkan hasil uji t hitung sebesar 6,555 dan angka signifikasi sebesar 0,000 . Besar nilai t tabel dengan tingkat $\alpha=5 \%(0,05)$, derajat kebebasan $\mathrm{n}-2(50-2=48)$. Maka diperoleh nilai $\mathrm{t}$ tabel $=2,010$ dikarenakan $\mathrm{t}$ hitung $>\mathrm{t}$ tabel yaitu 6,555 > 2,010 maka $\mathrm{H}_{\mathrm{o}}$ ditolak dan $\mathrm{H}_{\mathrm{a}}$ diterima, yang artinya Komunikasi $\left(\mathrm{X}_{2}\right)$ berpengaruh secara positif dan signifikan terhadap Kinerja Pegawai (Y).

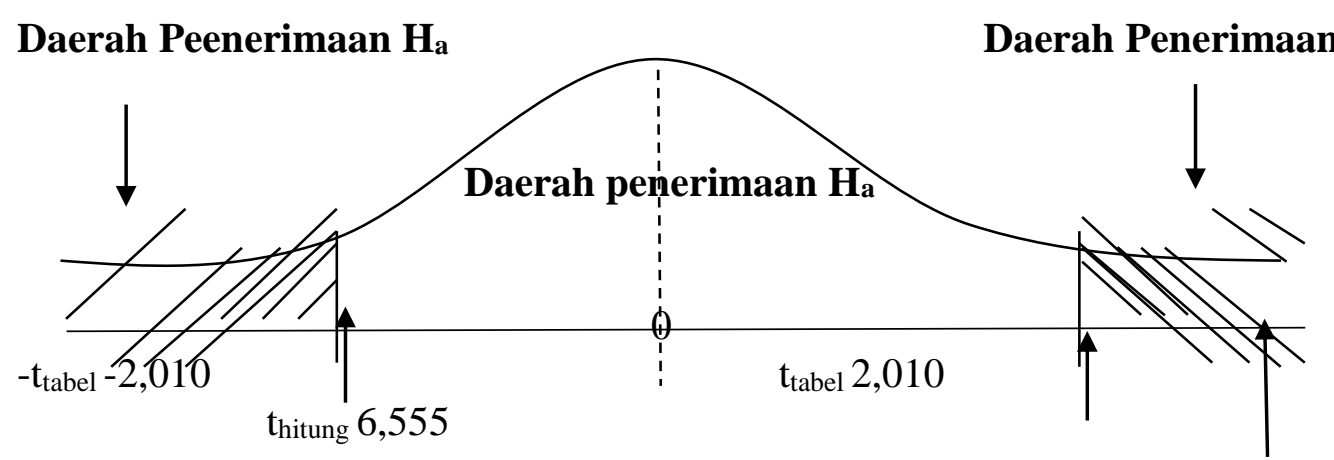

Gambar 2. Kurva Uji t Komunikasi (X2) Terhadap Kinerja Pegawai (Y)

Tabel 19. Uji t Disiplin Kerja Terhadap Kinerja Pegawai

\section{Coefficients $^{\mathrm{a}}$}

\begin{tabular}{|c|c|c|c|c|c|c|}
\hline & \multirow[b]{2}{*}{ Model } & \multicolumn{2}{|c|}{$\begin{array}{c}\text { Unstandardized } \\
\text { Coefficients }\end{array}$} & \multirow{2}{*}{\begin{tabular}{|c}
$\begin{array}{c}\text { Standardized } \\
\text { Coefficients }\end{array}$ \\
Beta \\
\end{tabular}} & \multirow[b]{2}{*}{$\mathrm{T}$} & \multirow[b]{2}{*}{ Sig. } \\
\hline & & B & Std. Error & & & \\
\hline 1 & $\begin{array}{l}\text { (Constant) } \\
\text { Disiplin Kerja }\end{array}$ & $\begin{array}{c}23,587 \\
, 491\end{array}$ & $\begin{array}{c}3,327 \\
, 079 \\
\end{array}$ & ,665 & $\begin{array}{l}7,089 \\
6,173\end{array}$ & $\begin{array}{l}, 000 \\
, 000\end{array}$ \\
\hline
\end{tabular}

a. Dependent Variable: Kinerja Pegawai

Sumber: data diolah menggunakan spss 25, tahun 2018

Untuk menguji hipotesis yang bersifat parsial antara Disiplin Kerja $\left(\mathrm{X}_{3}\right)$ terhadap Kinerja Pegawai (Y) digunakan uji t. Berdasarkan tabel 4.54. diatas menunjukkan hasil uji t hitung sebesar 6,173 dan angka signifikasi sebesar 0,000. Besar nilai t tabel dengan tingkat $\alpha=5 \%$ $(0,05)$, derajat kebebasan $\mathrm{n}-2(50-2=48)$. Maka diperoleh nilai $\mathrm{t}$ tabel $=2,010$ dikarenakan $\mathrm{t}$ hitung > t tabel yaitu 6,173 > 2,010 maka $\mathrm{H}_{\mathrm{o}}$ ditolak dan $\mathrm{H}_{\mathrm{a}}$ diterima, yang artinya Disiplin Kerja $\left(\mathrm{X}_{3}\right)$ berpengaruh secara positif dan signifikan terhadap Kinerja Pegawai (Y). 


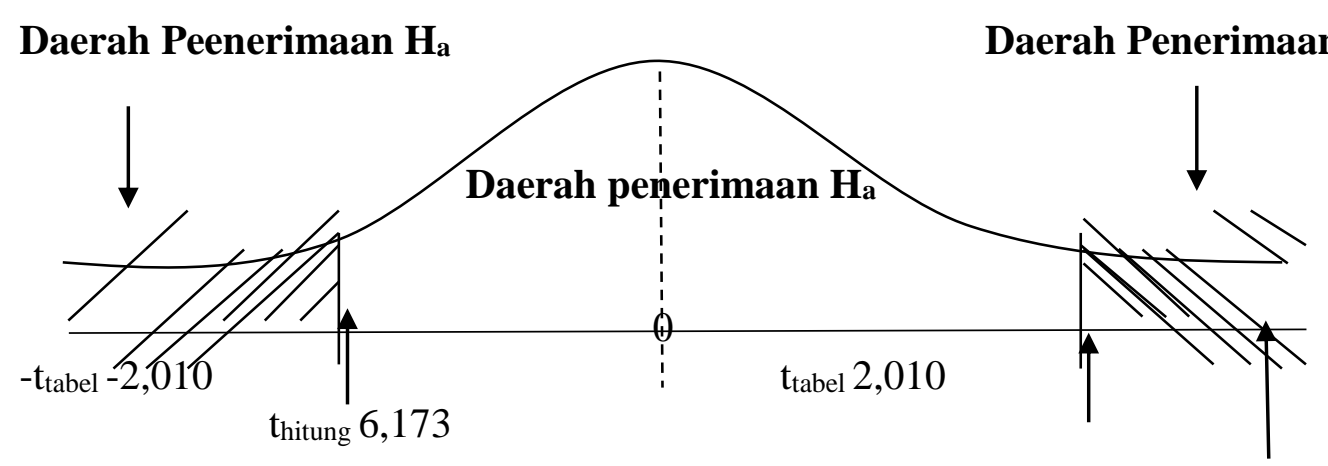

Gambar 3. Kurva Uji t Disiplin Kerja $\left(\mathrm{X}_{3}\right)$ Terhadap Kinerja Pegawai (Y)

\section{Uji f}

Uji f untuk menguji variabel bebas (independen) secara bersama-sama terhadap variabel terikat (dependen). Untuk melakukan uji f tersebut menggunakan program SPSS 25 for windows.

Tabel 20. Uji f

\section{ANOVA $^{\mathrm{a}}$}

\begin{tabular}{|c|c|c|c|c|c|c|}
\hline Mode & & \begin{tabular}{|l} 
Sum \\
Squares
\end{tabular} & Df & Mean Square & $F$ & Sig. \\
\hline \multirow[t]{3}{*}{1} & Regression & 383,561 & 3 & 127,854 & 20,044 &, $000^{b}$ \\
\hline & Residual & 293,419 & 46 & 6,379 & & \\
\hline & Total & 676,980 & 49 & & & \\
\hline
\end{tabular}

a. Dependent Variable: Kinerja Pegawai

b. Predictors: (Constant), Disiplin Kerja, Kompensasi, Komunikasi

Sumber: data diolah menggunakan spss 25, tahun 2018

Dari tabel 4.55. diatas menunjukkan bahwa hasil uji f hitung $=20,044$ untuk membuktikan maka dilakukan peerhitungan $\mathrm{f}$ hitung yang selanjutnya akan dikonsultasikan pada $\mathrm{f}$ tabel. Dicari dengan didasarkan pada $\mathrm{dk}$ pembilang $=\mathrm{k}$ dan $\mathrm{dk}$ penyebut $=(\mathrm{n}-\mathrm{k}-1)$, dengan taraf $5 \% \mathrm{dk}$ penyebut $=46$, maka diperoleh $\mathrm{f}$ tabel $=2,81$. Dengan demikian hasil perbandingannya adalah $20,044>2,81$, maka $\mathrm{H}_{\mathrm{o}}$ ditolak dan $\mathrm{H}_{\mathrm{a}}$ diterima. Dapat disimpulkan bahwa terdapat pengaruh yang positif dan signifikan antara Kompensasi, Komunikasi dan Disiplin Kerja secara bersamasama terhadap Kinerja Pegawai.

\section{Koefisien Determinasi}

Tabel 21. Koefisien Determinasi

Model Summary

\begin{tabular}{l|l|l|l|l}
\hline Model & $\mathrm{R}$ & R Square & $\begin{array}{l}\text { Adjusted } \\
\text { Square }\end{array}$ & $\begin{array}{c}\text { R } \\
\text { Std. Error of the } \\
\text { Estimate }\end{array}$ \\
\hline 1 &, $753^{\mathrm{a}}$ &, 567 &, 538 & 2,526 \\
\hline
\end{tabular}

a. Predictors: (Constant), Disiplin Kerja, Kompensasi, Komunikasi

b. Dependent Variable: Kinerja Pegawai

Sumber: data diolah menggunakan spss 25, tahun 2018 
Berdasarkan tabel 21. dijelaskan bahwa $\mathrm{R}$ square $\left(\mathrm{R}^{2}\right)$ adalah 0,567 menunjukkan besarnya pengaruh Kompensasi, Komunikasi dan Disiplin Kerja secara simultan terhadap Kinerja Pegawai adalah $56,7 \%$. Adapun sisanya sebesar $43,3 \%$ dipengaruhi oleh faktor lain.

\section{Simpulan/Conclusion}

Setelah penulis melakukan penelitian tentang pengaruh Kompensasi, Komunikasi dan Disiplin Kerja terhadap Kinerja Pegawai di Kecamatan Jambe Kabupaten Tangerang. Dapat disimpulkan bahwa hasil analisis stastistik dengan menggunakan SPSS versi 25 adalah sebagai berikut:

1. Hasil pengujian variabel Kompensasi terhadap Kinerja Pegawai secara parsial dengan menggunakan uji t mengatakan bahwa Kompensasi berpengaruh terhadap Kinerja Pegawai. Hal ini dapat dilihat dari nilai t hitung yang diperoleh sebesar 5,654 dengan tingkat signifikasi sebesar 0,00. Dikarenakan $t$ hitung $>\mathrm{t}$ tabel $(5,654>2,010)$ dan tingkat signifikasi $<0,05$ $(0,000<0,05)$. Maka hipotesis yang diajukan dapat diterima, semakin meningkatnya Kompensasi maka akan semakin meningkatkan Kinerja Pegawai di Kantor Kecamatan Jambe Kabupaten Tangerang.

2. Hasil pengujian variabel Komunikasi terhadap Kinerja Pegawai secara parsial dengan menggunakan uji t mengatakan bahwa Komunikasi berpengaruh terhadap Kinerja Pegawai. Hal ini dapat dilihat dari nilai t hitung yang diperoleh sebesar 6,555 dengan tingkat signifikasi sebesar 0,00. Dikarenakan $t$ hitung $>\mathrm{t}$ tabel $(6,555>2,010)$ dan tingkat signifikasi $<0,05$ $(0,000<0,05)$. Maka hipotesis yang diajukan dapat diterima, semakin meningkatnya komunikasi maka akan semakin meningkatkan Kinerja Pegawai di Kantor Kecamatan Jambe Kabupaten Tangerang.

3. Hasil pengujian variabel Disiplin Kerja terhadap Kinerja Pegawai secara parsial dengan menggunakan uji t mengatakan bahwa Disiplin Kerja berpengaruh terhadap Kinerja Pegawai. Hal ini dapat dilihat dari nilai t hitung yang diperoleh sebesar 6,173 dengan tingkat signifikasi sebesar 0,00 . Dikarenakan $t$ hitung $>\mathrm{t}$ tabel $(6,173>2,010)$ dan tingkat signifikasi $<0,05$ $(0,000<0,05)$.

Maka hipotesis yang diajukan dapat diterima, semakin meningkatnya Disiplin Kerja maka akan semakin meningkatkan Kinerja Pegawai di Kantor Kecamatan Jambe Kabupaten Tangerang.

4. Berdasarkan uji simultan (uji F) yang dilakukan dapat dilihat bahwa nilai $\mathrm{F}$ hitung diperoleh sebesar 20,044 dengan tingkat signifikasi 0,000. Sedangkat $F$ tabel 2,81 dengan nilai

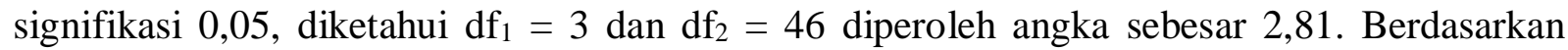
kriteria uji $\mathrm{F}$ yang telah ditentukan pada bab sebelumnya oleh karena $\mathrm{F}$ hitung $>\mathrm{F}$ tabel (20,044 > 2,81) dan disimpulkan bahwa Kompensasi, Komunikasi dan Disiplin Kerja secara bersama-sama berpengaruh positif dan signifikan terhadap Kinerja Pegawai di Kecamatan Jambe Kabupaten Tangerang. Dan Uji Koefisien Determinasi menunjukkan bahwa 56,7\% tingkat Kinerja Pegawai dapat dijelaskan oleh ketiga variabel independen sedangkan sisanya 43,3\% dipengaruhi oleh variabel lain.

\section{Ucapan Terima Kasih/Acknowledgement}

Penulis mengucapkan terima kasih yang sebanyak-banyaknya kepada Dwi Hawa Asy Asyifa yang telah membantu dalam proses penginputan data serta Acep Kurnaen, SE Kasie Trantib dan Linmas yang telah membantu akses penelitian di lokasi ini.

\section{Daftar Pustaka}

Hasibuan, M. S. (2012). Manajemen Sumber Daya Manusia: edisi revisi. Jakarta: PT Bumi Aksara.

Mulyana, D. (2011). Ilmu Komunikasi . Bandung: PT. Remaja Rosdakarya. 
Sugiyono. (2012). Metode Penelitian Bisnis. Bandung: CV Alfabeta.

Veithzal, R., \& Sagala, E. J. (2009). Manajemen Sumber Daya Manusia untuk perusahaan dari teori ke praktik. Jakarta: PT. Raja Grafindo Persada.

Yanti, L. D., \& Oktari, Y. (2018). Pengaruh Tingkat Profitability, Solvability, Ukuran Perusahaan dan Ukuran Kantor Akuntan Publik Pada Penundaan pemeriksaan (Studi Empiris : Perusahaan Manufaktur Terdaftar di BEI Tahun 2013-2016). eCo-Buss, 15-32. 